of the provinces. It is written jointly by R. A. Maher and G. W. Argus of the Rare and Endangered Plants Project of the National Herbarium, and V. L. Harms and J. H. Hudson of the W. P. Fraser Herbarium of the University of Saskatchewan. It is an annotated list with information on the distribution and habitats of the plants in Saskatchewan, their status in the rest of Canada and in the United States, and the legal protection afforded them. Provincial distribution maps and an extensive bibliography are included.

In the introduction, the aims of the Rare and Endangered Plants Project are discussed, and the phytogeography of rare plants and their protection in Saskatchewan is reviewed.

Copies are available free from The Rare and Endangered Plants Project, Botany Division, National Museum of Natural Sciences, Ottawa, K1A OM8.

\section{NATURE AND CHANGE ON THE CANADIAN PLAINS}

The proceedings of the 1977 Annual Meeting of the Canadian Nature Federation have been published by the Canadian Plains Research Center as Nature and Change on the Canadian Plains.

Editor W. A. Davies selected and edited papers to provide a comprehensive view of the Regina conference. The more than 200 page publication is available for $\$ 7.00$ from the Canadian Plains Research Center, University of Regina, or the Blue Jay Bookshop.

\section{INLAND BIRD BANDING}

The Inland Bird Bandin Association is making a number changes to their journal. It is no called Inland Bird Banding, and w be a quarterly refereed journ similar in format to the Wilso Bulletin. They are solicitin manuscripts less than 10 pages length dealing with bird bandin techniques and the results of bir banding studies. Please sen material to the Editor, Jerome $A$ Jackson, Dept. of Biological Scien ces, Mississippi State University Mississippi State, Mississippi 39762

\section{BLUEBIRD MAGAZINE}

Bluebird enthusiasts will welcom the formation of The North Americar Bluebird Society and their nev magazine Sialia. The first 40 pag issue carries a wide range of article including a profile of the late Joh Lane of Brandon.

Memberships in the Society including a subscription to the quar. terly journal are available for $\$ 10.00$ from Box 6295, Silver Springs Maryland 20906.

\section{SUMMER MEETING AT EASTEND, SASKATCHEWAN}

The 1979 annual summer field meeting will be held at Eastend, Saskatchewan on June 15-16, 1979. Guided trips and illustrated talks will help naturalists to become familiar with this section of southwestern Saskatchewan. Details of the meeting arrangements will be published in the Spring issue of the SNHS Newsletter. 